\title{
Kajian Kualitas Beras Sosoh dari berbagai Macam Ukuran Daya Mesin Penggiling
}

\author{
Study of Milling Rice Quality from Various Power Sizes of Grinding Machines \\ Ida Bagus Werdi Putra, Yohanes Setiyo, I Gusti Ngurah Apriadi Aviantara \\ Program Studi Teknik Pertanian, Fakultas Teknologi Pertanian, Unud \\ *Email: setiyoyohanes@yahoo.com
}

\begin{abstract}
Abstrak
Beras merupakan makannan pokok bagi masyarakat Indonesia. Walaupun pada dasarnya Indonesia merupakan Negara yang agraris, namun saat ini Indonesia masih mengimpor beras. Dalam menghasilkan beras dari padi terdapat kendala. Salah satu kendala utama adalah penanganan pasca panen padi dengan tingginya kehilangan hasil selama pasca panen. Besarnya kehilangan pasca panen terjadi karena sebagian besar petani masih menggunakan cara-cara tradisional atau penanganannya belum baik dan benar. Tujuan dari penelitian ini adalah untuk mengetahui hubungan kapasitas mesin penggiling dengan kualitas beras sosoh hasil gilingan dan mengetahui perbandingan mutu dari berbagai macam kapasitas mesin penggiling. Penelitian dilakukan di wilayah Desa Wanasari, Tabanan-Bali untuk mengetahui kualitas beras sosoh yang berada di wilayah tersebut. Beras kepala merupakan butiran beras pecah, baik yang sehat maupun cacat, yang memiliki ukuran lebih besar atau sama dengan 6/10 bagian dari ukuran panjang rata-rata butiran padi utuh yang dapat melewati permukaan cekungan lempeng indentasi dengan persyaratan ukuran lubang 4,2 $\mathrm{mm}$. Sekam beras adalah penutup pelindung dari butiran beras yang dipisahkan dari biji selama proses penggilingan. Dalam proses penggilingan, ada beras yang tetap menjadi sekam yang disebabkan oleh daya / rpm dari mesin penggiling yang terlalu rendah karena gaya gesekan yang dihasilkan oleh mesin tidak cukup untuk pelepasan sekam padi secara keseluruhan.
\end{abstract}

Kata Kunci: beras kepala, beras sosoh, mesin penggiling, sekam

\begin{abstract}
Rice is a staple food for the people of Indonesia. Even though Indonesia is an agrarian country, Indonesia currently imports rice. In producing rice from rice there are obstacles. One of the main obstacles is postharvest handling of rice with high yield loss during post-harvest. The amount of post-harvest loss occurs because most farmers still use traditional method or the handling is not good and right. The purpose of this study was to determine the relationship between the capacity of the grinding machine and the quality of sosoh rice produced by the mill and to know the quality comparison of various types of grinding machine capacity. The research was carried out in the area of Wanasari Village, Tabanan-Bali to find out the quality of sosoh rice in the region. Head Rice is broken rice grains, both healthy and defective, which have a size greater than or equal to $6 / 10$ part of the average length size of whole rice grains that can pass through the surface of the indented plate basin with a requirement of $4.2 \mathrm{~mm}$ hole size. Rice hull is a protective cover from rice grains which is separated from seeds during the grinding process. In the grinding process, there is rice which remains the husk which is caused by the power / rpm of the grinding machine which is too low because the friction force produced by the engine is not sufficient for the overall release of rice hull.
\end{abstract}

Keywords: polished rice, grinding machine, head rice, rice hull

\section{PENDAHULUAN}

Di Indonesia, masalah beras erat kaitannya dengan masalah sosial, budaya dan ekonomi bangsa. Dalam bidang ekonomi beras digunakan sebagai indeks kestabilan nasional. Hal ini diakibatkan oleh posisi strategis beras yang berperan sebagai makanan pokok bagi masyarakaat Indonesia.Walaupun pada dasarnya Indonesia adalah negara agraris, namun sampai saat ini Indonesia masih mengimpor beras. Menurut Badan Pusat Statistik (BPS), pada tahun 2016 Indonesia mengimpor beras sebanyak 1,2 juta ton. Impor beras yang cukup besar di 2016 tersebut merupakan sisa dari kontrak impor tahun 2015.

Masalah utama pada penanganan pasca panen padi adalah tingginya kehilangan hasil selama pasca panen. Kegiatan pasca panen meliputi proses 
pemanenan padi, penyimpanan padi, pengeringan gabah, dan penggilingan gabah hingga menjadi beras. BPS (2013) menyebutkan kehilangan hasil panen dan pasca panen akibat dari ketidak sempurnaan penanganan pasca panen mencapai $20,51 \%$, dimana kehilangan saat pemanenan $9,52 \%$, perontokan $4,78 \%$, pengeringan $2,13 \%$ dan penggilingan $2,19 \%$. Besarnya kehilangan pasca panen terjadi kemungkinan dikarenakan sebagian besar petani masih menggunakan cara-cara tradisional atau meskipun sudah menggunakan peralatan mekanis tetapi proses penanganan pasca panennya masih belum baik dan benar. Menurut Kasma Iswari (2013) kontribusi penggunaan alat dan mesin panen dan pascapanen sangat besar, yaitu menurunkan kehilangan hasil dari $21,09 \%$ pada cara petani menjadi $6,60 \%$ dengan menggunakan alat dan mesin.

Penggilingan padi berusaha menyosoh padinya dengan cara memberi tekanan berlebihan terhadap butir beras saat penyosohan sehingga beras banyak yang patah dan pecah. Proses penyosohan beras giling lebih banyak terjadi secara fisik dibanding cara kimia Katsuragi, (1995). Hasil penelitian Umar (2003), penekanan terhadap butir beras dalam hal putaran mesin sosoh yang sangat tinggi pada permukaan beras dipengaruhi oleh besarnya putaran silinder sehingga butir beras akan mengalami kepatahan. Dengan kecepatan linier optimum dari mesin penyosoh $(734 \mathrm{rpm})$ dapat meningkatkan mutu beras yang diukur dari rendemen giling $(74,68$ $\%)$, beras kepala $(87,48 \%)$ dan beras patah $(8,90 \%)$ pada batas kadar air $\pm 13 \%$. Susut mutu dari suatu hasil giling dapat diidentifikasikan dalam nilai derajat sosoh serta ukuran dan sifat butir padi yang dihasilkan. Umumnya semakin tinggi derajat sosoh, persentase beras patah akan menjadi semakin meningkat.

Daya yang umum digunakan dalam mesin penggilingan gabah tersebut berkisar $6 \mathrm{PK}$ sampai 120 PK dan memiliki kapasitas mesin berkisar 1 sampai 20 ton/jam Susrusa et al, (2015). Mengingat kadar air padi hasil panen sangat bervariasi antara 18-25\%, bahkan dalam beberapa kasus dapat lebih besar. Oleh karena itu, sebelum dilakukan penggilingan, pengeringan dilakukan untuk mengurangi kadar air sampai sekitar 14\% sehingga memudahkan dan mengurangi kerusakan dalam penyosohan dan proses selanjutnya.

Susut mutu dari suatu hasil giling dapat diidentifikasikan dalam nilai derajat sosoh serta ukuran dan sifat butir padi yang dihasilkan. Umumnya semakin tinggi persentase derajat sosoh, maka bobot pada beras akan semakin berkurang dan memungkinkan terbentuknya beras patah menjadi semakin meningkat pula (Hasbullah, dkk 2009). Ukuran butir beras hasil giling dibedakan atas beras kepala, beras patah, dan menir Anonim, (1983). Berdasarkan persyaratan yang dikeluarkan oleh Bulog, beras kepala merupakan beras yang memiliki ukuran lebih besar dari 6/10 bagian beras utuh. Beras patah memiliki ukuran butiran 2/10 bagian sampai 6/10 bagian beras utuh. Menir memiliki ukuran lebih kecil dari 2/10 bagian beras utuh atau melewati lubang ayakan $2.0 \mathrm{~mm}$ Waries, (2006).

Sesuai dengan uraian tersebut, maka tujuan dari penelitian ini adalah menganalisis dampak kapasitas mesin penggiling terhadap kualitas beras pecah kulit dan beras sosoh. Sedangkan hipotesis penelitian adalah semakin besar kapasistas mesin penggiling gabah maka kualitas beras pecah kulit dan beras sososh yang dihasilkan juga meningkat.

\section{METODE PENELITIAN}

\section{Waktu dan Tempat Penelitian}

Penelitian ini dilaksanakan pada Oktober-Desember 2017. Tempat penelitian adalah beberapa usaha penggilingan gabah di Kecamatan Penebel Kabupaten Tabanan, Propinsi Bali. Analisis kualitas gabah dan beras dilakukan di laboratorium Teknik Pascapanen PS. Tekik Pertanian, FTP-Unud.

\section{Bahan dan Alat}

Subyek penelitian adalah analisis kulitas beras sosoh kualitas beras sosoh, hasil proses penggilingan dengan daya mesin yang berbeda. Bahan yang digunakan dalam penelitian ini adalah gabah hasil panen di Kecamatan Penebel Kabupaten Tabanan, varietasnya adalah IR 34, umur panen 100 hari, dan yang dikeringkan sampai kadar air $14 \%$ dasar basah. Setelah padi dikeringkan dan digiling beras hasil penggilingan juga dijadikan bahan analisa.

Alat-alat penelitian berupa : lantai jemur, mesin pengering mekanis, mesin penggiling padi (kapasitas kerja 0,2 - 1 ton/jam, 1 - 2 ton/jam, $2-$ 6 ton/jam, dan lebih dari 6 ton/jam), timbangan duduk dan timbangan analitis, oven, thermometer, hygrometer, panci, dan plastik. Alat lain dalam penelitian adalah kuistener untuk mendapatkan data sekunder.

\section{Prosedur Penelitian}

Penelitian dilakukan dengan Rancangan Acak Lengkap (RAL) empat perlakuan. Penelitian ini di dukung dengan penelitian ND Sartika, Z Ramdhani (2018) Perlakuan A penggilingan dengan mesin penggiling gabah kapasitas kurang 
dari 0,2 - 1 ton/jam, perlakuan B penggilingan dengan mesin penggiling gabah kapasitas kurang dari $1-2$ ton/jam, perlakuan $\mathrm{C}$ penggilingan dengan mesin penggiling gabah kapasitas kurang dari $2-6$ ton/jam, perlakuan D penggilingan dengan mesin penggiling gabah kapasitas lebih dari 6 ton/jam. Setiap perlakuan diulangi di tiga kali, setiap perlakuan gabah yang digiling adalah 1 ton. Mesin penggiling dioperasikan pada stelan gas yang seragam.

\section{Pengambilan Data Penelitian}

Penelitian dibagi menjadi tiga tahapan, yaitu : (1) penelitian kualitas gabah hasil pengeringan, (2) penelitian kualitas gabah pecah kulit, dan (3) penelitian kualitas beras sosoh. Penelitian tahap 2 dilakukan dengan daya mesin dan kapasitas penggiling gabah.

\section{Penggilingan Gabah}

Penggilingan gabah dilakukan dengan menggunakan rice milling unit sesuai perlakuan dengan mesin penggiling tahun 1997-2013. Spesifikasi, daftar nama usaha, dan kapasitas mesin penggiling dapat dibaca di Lampiran 1. Rice milling unit terdiri dari mesin pemecah kulit dan mesin sosoh. Gabah yang digiling memiliki kadar air $14 \pm 1 \%$ w.b. parameter mutu beras yang diamati adalah : (1) \% beras kepala, (2) \% beras pecah, (3) $\%$ menir, dan (4) benda asing.

\section{Kapasitas Kerja Penggilingan}

Variabel penelitian adalah kinerja penggilingan gabah (kapasitas kerja dan kualitas kerja) dengan mesin penggiling yang berbeda daya mesin. Variabel kapasitas kerja dengan parameter yang diukur adalah: jumlah gabah yang digiling dan waktu untuk penggilingan. Menghitung kapasitas giling $(\mathrm{kgl})$ dihitung dengan persamaan.

$$
K g l(\mathrm{~kg} / \text { menit })=\frac{B . G K G}{W P G}
$$

Keterangan: B.GKG : bobot gabah kering giling

$(\mathrm{kg})$

WPG :waktu penggilingan gabah menjadi beras (menit)

\section{Kualitas Hasil Kerja Penggilingan Beras Pecah Kulit dan Beras Sosoh \\ Variabel kualitas hasil kerja dinilai terhadap parameter-parameter: $\%$ beras utuh, $\%$ beras pecah, $\%$ menir dan \% gabah tidak terkupas kulitnya. Kapasitas kerja dan kualitas kerja dinilai pada saat penyosohan dan pemutihan beras.}

Derajat sosoh memiliki beberapa tingkatan kategori mutu dalam standar beras SNI di antaranya derajat sosoh $100 \%$ masuk kategori mutu 1 dan II, derajat sosoh 95\% masuk kategori mutu III dan IV dan derajat sosoh $85 \%$ masuk kategori mutu V. penentuan derajat sosoh dilakukan dengan perbanding contoh derajat sosoh yang ada di BULOG.

1. Persentase beras kepala

Persentase beras kepala (bk) dihitung dengan persamaan.

$$
b k(\%)=\frac{B B B K}{B s} \times 100 \%
$$

Keterangan : BBBK : bobot butir beras kepala (gram)

BS : bobot sampel/contoh (gram)

2. Mencari persentase beras pecah

Persentase beras pecah (bp) dihitung dengan persamaan.

$$
b p(\%)=\frac{B B B P}{B s} \times 100 \%
$$

Keterangan : BBBP : bobot butir beras pecah (gram)

Bs : bobot sampel/ contoh (gram)

3. Menentukan persentase menir

Persentase butir menir (bm) dihitung dengan persamaan.

$$
\begin{aligned}
\operatorname{bm}(\%)= & \frac{B M}{B s} \times 100 \% \\
\text { Keterangan : } & \text { BM : bobot menir (gram) } \\
& \text { Bs : bobot sampel/contoh (gram) }
\end{aligned}
$$

\section{Metode Analisis Data}

Data hasil penelitian yang berupa kapasitas kerja, beras utuh, beras pecah, menir, dan benda asing dari hasil penggilingan beras pecah kulit dan penyosohan dianalisis dengan analisis sidik ragam (ANOVA). Apabila ada perbedaan yang signifikan antar perlakuan maka rata-rata nilai parameter tadi dilanjutkan dengan uji beda nyata terkecil dengan metode Duncan.

\section{HASIL DAN PEMBAHASAN}

\section{Hasil Kinerja Penggilingan Padi dan Penyosohan Beras}

Dari proses penggilingan gabah dan penyosohan beras sebanyak 1 ton gabah dan beras pecah kulit dimasukan pada mesin poenggiling sesuai dengan perlakuan kapasitas mesin penggiling. Dari hasil uji mesin penggiling un tuk pecah kulit dan penyosohan didapatkan data sesuai dengan Gambar 1. 


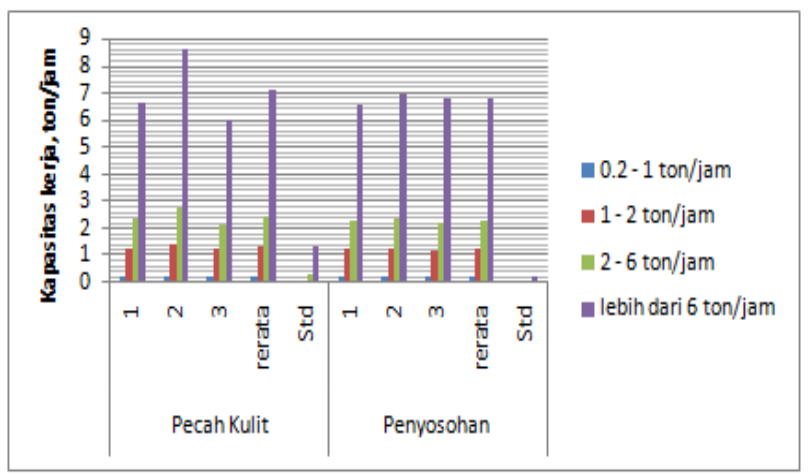

Gambar 1 Kinerja Mesin Penggiling Padi dan penyosohan Beras

Dari hasil uji kapasitas kerja mesin penggiling padi pada proses pengupasan kulit (sekam) dari beras didapatkan kapasitas kerja rata-rata untuk setiap perlakuan masing-masing $0,21 \pm 0,003$ ton/jam, $1,32 \pm 0,09$ ton/jam, $2,42 \pm 0,29$ ton/jam dan 7,08 \pm 1,33 ton/jam dari mesin penggiling yang memiliki spesifikasi teknis kapasitas kerja rata-rata 0,3 ton/jam, 1,5 ton/jam, 2,4 ton/jam dan 7,0 ton/jam. Waktu untuk penggilingan 1 ton gabah pada proses beras pecah kulit untuk mesin penggiling kapasitas $0.2-1$ ton/jam, $1-2$ ton/jam, $2-6$ ton/jam dan lebih dari 6 ton/jam adalah $276 \pm 4$ menit, 45,33 $\pm 3,05$ menit,25,00 $\pm 3,00$ menit,dan $8,66 \pm 1,52$ menit. Sedangkan waktu penyosohan beras 1 ton untuk mesin ppenyosoh beras berkapasitas $0.2-1$ ton/jam, $1-2$ ton/jam, $2-6$ ton/jam dan lebih dari 6 ton/jam adalah 256,68 \pm 4,23 menit, $48,43 \pm 0,51$ menit,26,10 $\pm 0,82$ menit,dan $8,86 \pm 0,31$ menit.

\section{Hasil Efisiensi Kerja Mesin Penggiling Gabah}

Peningkatan kapasitas mesin giling berpengaruh sangat nyata pada efisiensi kerja mesin penggiling gabah pecah kulit dan penyosohan beras dengan nilai $\mathbf{P}>0,01$. Ilustrasi efisiensi mesin penggiling gabah dhubungannya dengan kapasitas mesin penggiling seperti Gambar 2. Mesin penggiling gabah tersebut yang memiliki spesifikasi teknis kapasitas kerja rata-rata 0,3 ton/jam, 1,5 ton/jam, 2,4 ton/jam dan 7,0 ton/jam, masing-masing memiliki efisiensi kerja sebesar 75,01 $\pm 1,9 \%, 88,5 \pm 0,6 \%$, $90,08 \pm 0,89 \%$ dan $87,30 \pm 0,9 \%$. Mesin penyosoh beras yang memiliki spesifikasi teknis $0.2-1$ ton/jam, $1-2$ ton/jam, $2-6$ ton/jam dan lebih dari 6 ton/jam adalah masing-masing memiliki efisiensi kerja sebesar $81,01 \pm 1,9 \%, 82,59 \pm 0,8 \%, 86,07 \pm$ $0,6 \%$ dan $87,29 \pm 0,09 \%$.

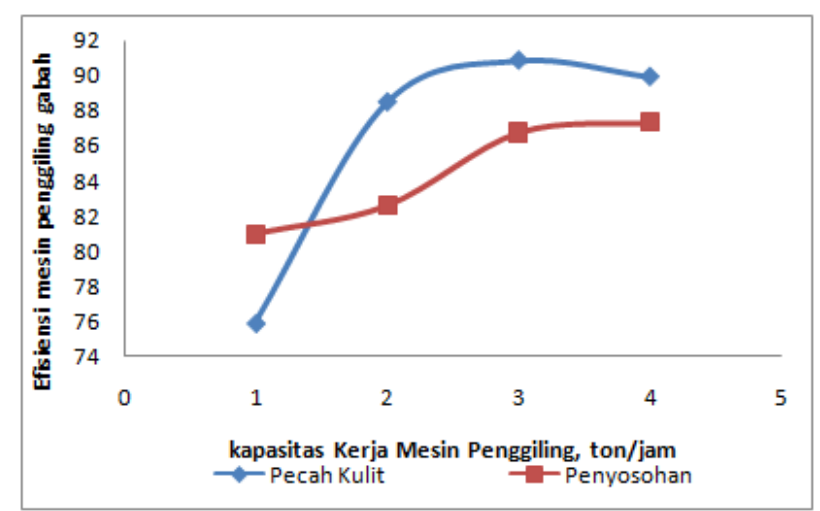

Gambar 2. Efisiensi Kerja Mesin Penggiling Gabah

\section{Hasil Kualitas Kerja Penggilingan dan Penyosohan}

Demikian pula kinerja proses penyosohan beras oleh mesin penggiling yang memiliki kapasitas penyosohan berbeda berpengaruh secara sangat signifikan pada kapasitas kerja dan efisiensi kerja mesin. Dari proses penggilingan gabah sebanyak 1 ton untuk proses penyosohan beras didapatkan datadata seperti Tabel 2. Dari hasil uji coba peningkatan kapasisitas mesin penggiling berdampak pada kapasitas kerja efektif mesin.Efisiensi kerja mesin dengan kapasitas $0,2-1$ ton/jam, $1-2$ ton/jam, $2-$ 6 ton/jam dan lebih dari 6 ton/jam masing-masing adalah $29,52-90,22 \%, 83,33-95,23 \%, 71,77-$ $85,71 \%$ dan 83,33 - 92,30 \%. Hasil ini sesuai dengan penelitian Sri Widowati (2001) dari data kinerja mesin penggiling maka makin besar kapasitas mesin menyebabkan efisiensi kerja mesin semakin tinggi, selain itu dari ulangan kinerja mesin penggiling dengan daya yang berdekatan didapatkan fakta efisiensi kerja mesin penyosoh beras menurun dengan meningkatnya umur mesin. Secara statistik kapasitas dan efisiensi mesin penggiling berbeda sangat nyata $(\mathrm{P}>0,01)$ apabila daya mesinnya berbeda.

Tabel 1 Kinerja Mesin Penggiling pada Proses Penggilingan Gabah

\begin{tabular}{|c|c|c|c|c|}
\hline \multirow{2}{*}{$\begin{array}{l}\text { PerlakuanMesin } \\
\text { Penggiling Padi }\end{array}$} & \multicolumn{4}{|c|}{ Kualitas Hasil Kerja Mesin Penggiling Gabah Pecah Kulit } \\
\hline & $\begin{array}{c}\text { Beras Kepala, } \\
\%\end{array}$ & $\begin{array}{c}\text { Beras pecah, } \\
\%\end{array}$ & Menir, \% & $\begin{array}{c}\text { Beras masih } \\
\text { Ada Sekam, } \%\end{array}$ \\
\hline $0,2-1$ ton $/ \mathrm{jam}$ & $28,13 a \pm 3,56$ & $41,33 \mathrm{~b} \pm 2,48$ & $15,47 a \pm 1,75$ & $15,07 \mathbf{a} \pm 4,64$ \\
\hline $1-2$ ton $/ \mathrm{jam}$ & $39,87 a \pm 0,42$ & $44,67 a \pm 1,55$ & $8,60 \mathrm{ab} \pm 0,4$ & $6,87 \mathrm{~b} \pm 1,67$ \\
\hline $2-6$ ton/jam & $50,07 \mathbf{a} \pm 4,50$ & $40,00 \mathrm{~b} \pm 3,82$ & $6,2 \mathrm{~b} \pm 0,2$ & $3,73 \mathrm{~b} \pm 0,95$ \\
\hline $\begin{array}{l}\text { lebih dari } 6 \\
\text { ton/jam }\end{array}$ & $49,27 \mathbf{a} \pm 0,64$ & $40,40 \mathrm{~b} \pm 0,53$ & $5,20 \mathrm{~b} \pm 0,72$ & $5,13 \mathrm{~b} \pm 1,21$ \\
\hline
\end{tabular}


Tabel 2 Kinerja mesin penggiling padi pada proses penyosohan

\begin{tabular}{|c|c|c|c|c|}
\hline \multirow{2}{*}{$\begin{array}{l}\text { Kapasitas } \\
\text { mesin } \\
\text { Pengijing }\end{array}$} & \multicolumn{4}{|c|}{ Kinerja mesin penggiling } \\
\hline & $\begin{array}{c}\text { Beras } \\
\text { Kepala, \% }\end{array}$ & $\begin{array}{c}\text { Beras } \\
\text { Pecah, \% }\end{array}$ & Menir, \% & $\begin{array}{c}\text { Benda asing. } \\
\%\end{array}$ \\
\hline $\begin{array}{l}0,2-1 \\
\text { ton/jam }\end{array}$ & $28,6 \pm 3,36$ & $40,53 \pm 1,55$ & $16,20 \pm 1,91$ & $14,67 \pm 4,01$ \\
\hline $1-2$ ton/jam & $39,07 \pm 1,33$ & $44,67 \pm 1,55$ & $8,47 \pm 0,46$ & $7,80 \pm 0,40$ \\
\hline $2-6$ ton $/ \mathrm{jam}$ & $48,00 \pm 1,11$ & $41,47 \pm 1,29$ & $6,2 \pm 0,2$ & $4,33 \pm 0,81$ \\
\hline $\begin{array}{l}\text { lebih dari } 6 \\
\text { ton/jam }\end{array}$ & $48,73 \pm 0,31$ & $39,93 \pm 0,31$ & $5,53 \pm 0,50$ & $5,80 \pm 0,69$ \\
\hline
\end{tabular}

\section{Pembahasan}

Peningkatan kinerja mesin penggiling sangat dipengaruhi oleh : (1) kondisi mesin dari sisi umur, konstruksi bagian-bagian mesin dan perawatan, (2) pengoperasian mesin terutama penyetelan gas dan bagian-bagian yang bergerak yang secara langsung melakukan pelepasan sekam dari beras dan proses pemutihan beras dengan penyosohan, dan (3) kondisi lingkungan penggilingan. Dengan semakin besar kapasitas mesin pengiling padi maka konstruksi dan mekanisme kerja mesin penggiling terutama bagian-bagian yang secara langsung berhubungan dengan proses penggilingan akan semakin baik.

Bagian-bagian tersebut antara lain: unit pengumpan gabah atau beras, unit pemroses (ruber roll), unit separasi beras dengan sekam, unit keluaran hasil proses, serta unit penggerak masing-masing komponen mesin penggiling padi. Peningkatan kualitas konstruksi mesin dan mekanisme kerja mesin berdampak pada peningkatan kenyaman kerja pengoperasian mesin penggiling padi.

Peningkatan kapasitas kerja mesin penggiling padi sebagai dapak dari peningkatan daya penggerak mesin. Daya penggerak mesin berhubungan langsung dengan kecepatan putar (rpm) dari bagian yang secara langsung melakukan proses penggilingan, yaitu rubber roll. Mesin penggiling dengan kapasitas $0,2-1$ ton/jam , $1-2$ ton/jam, $2-$ 6 ton/jam dan lebih dari 6 ton/jam masing-masing memiliki rpm kerja ruber roll sebesar $0,2-1$ ton (830 Rpm), 1-2 ton (1100 Rpm), 2-6 ton (2800 Rpm), dan lebih dari 6 ton (3900 Rpm). Peningkatan rpm ruber roll berdampak secara langsung pada efektifitas pelepasan sekam dari beras, dan efektifitas pemutihan beras. Semakin tinggi kecepatan putar ruber roll maka gaya gesek yang dihasilkan oleh : (1) ruber rool dengan gabah/beras, dan (2) gabah dengan gabah atau beras dengan beras pada unit pemroses akan semakin tinggi pula, sehingga proses pengupasan sekam atau pemutihan beras semakin efektif.
Selain itu peningkatan rpm ruber roll juga berdampak pada kecepatan proses penggilingan, sehingga waktu efektif untuk massa gabah atau beras berada di rungan pemrosesan semakin pendek. Waktu penggilingan sangat erat kaitannya dengan efisiensi kerja mesin penggiling.

Dari hasil uji coba peningkatan kapasisitas mesin penggiling berdampak pada kapasitas kerja efektif mesin. Efisiensi kerja mesin dengan kapasitas 0,2 1 ton/jam, $1-2$ ton/jam, $2-6$ ton/jam dan lebih dari 6 ton/jam masing-masing adalah 27,5 - 87,5 $\%, 80-95 \%, 85-96 \%$ dan $83-92 \%$. Dari data kinerja mesin penggiling maka makin besar kapasitas mesin menyebabkan efisiensi kerja mesin semakin tinggi.Secara statistik kapasitas dan efisiensi mesin penggiling berbeda sangat nyata apabila daya mesinnya berbeda (Tabel 1).

Berdasarkan kinerja pemecahan kulit dari parameter beras kepala dan beras yang masih ada sekam, maka mesin dengan kapasitas $2-6$ ton/jam memiliki kinerja terbaik yaitu50,07 $\pm 4,50 \%$ beras kepala dengan beras yang ada sekamnya 3, 73 $\pm 0,95 \%$. Secara statistik mesin dengan kapasitas 0,2-1 ton

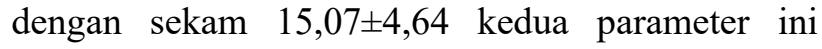
berbeda sangat nyata akibat perbedaan daya mesin penggiling. Apabila daya terlalu besar maka beras yang pecah semakin banyak, rpm mesin terlalu tinggi mengakibatkan beras pecah karena setiap beras mendapatkan gaya yang lebih besar. Namun jika daya mesin penggiling terlalu rendah, maka jumlah beras yang tidak terkelupas kulitnya semakin besar karena gaya gesek yang dihasilkan mesin tidak mencukupi untuk pelepasan sekam dari beras.

Dari Tabel 1 jumlah beras kepala dan menir untuk mesin penggiling dengan kapasitas lebih dari 6 ton/jam adalah $40,40 \pm 0,53 \%$ dan $5,20 \pm 0,72$, nilai ini adalah paling besar dibandingkan hasil penggilingan dari mesin dengan kapasitas di bawahnya. Hal ini menunjukan gaya gesek yang dihasilkan ruber roll untuk mengupas kulit gabah cukup besar dan berdampak pada pecahnya beras. Secara statistik jumlah beras pecah dan menir yang dihasilkan pada penggilingan dengan daya berbeda 
menunjukan bahwa sangat berbeda nyata $(\mathrm{P}>0,01)$, dengan demikian kapasitas daya mesin penggiling padi berdampak pada kinerja penggilingan terutama jumlah beras pecah dan menir.

\section{Kinerja Mesin Penggiling Proses Penyosohan}

Berdasarkan kinerja penyosohan dari parameter beras pecah dan menir, dan benda asing maka mesin dengan kapasitas $2-6$ ton/jam memiliki kinerja terbaik. Beras pecah hasil kerja mesin ini yaitu $41,47 \pm 1,29 \%$ dengan menir $6,2 \pm 0,2 \%$, serta benda asing $4,33 \pm 0,81$. Secara statistik ke tiga parameter ini berbeda sangat nyata akibat perbedaan daya mesin penggiling (Tabel 16, tabel 17 dan Tabel 18). Apabila daya terlalu besar maka beras yang pecah semakin banyak, rpm mesin terlalu tinggi mengakibatkan beras pecah karena setiap beras mendapatkan gaya yang lebih besar. Namun jika daya mesin penggiling terlalu rendah, maka jumlah beras yang tidak terkelupas kulitnya semakin besar karena gaya gesek yang dihasilkan mesin tidak mencukupi untuk pelepasan sekam dari beras. Menurut Nugraha (2012) konfigurasi penggilingan akan berpengaruh terhadap kualitas beras yang ditentukan dengan besaran derajat sosoh, persentase beras pecah maupun butir menir yang terjadi.

Semakin besar daya mesin penyosohan beras maka semakin baik kinerjanya, hal ini ditunjukan dari jumlah beras kepala pada mesin penyosoh dengan kapasitas lebih dari 6 ton/jam jumlah beras kepalanya $48,73 \pm 0,31 \%$, namun secara statistik tidak berbeda dengan kinerja mesin penyosoh kapasitas $2-6$ ton/jam yang menghasilkan jumlah beras utuh adalah $48,00 \pm 1,11 \%$.

\section{KESIMPULAN DAN SARAN}

\section{Kesimpulan}

Kualitas gabah yang digiling dengan mesin penggiling kapasitas $0,2-$ ton/jam, $1-2$ ton/jam, 2 -6 ton/jam dan lebih dari 6 ton/jam memiliki nilai kadar air 14,56 $\pm 0,03$ s/d 14,63 $\pm 0,29 \%$ w.b; gabah utuh $91 \pm 0,04-93 \pm 0,04 \%$; gabah hampa $2 \pm 0,001$ - $3 \pm 0,001$; gabah menguning $2 \pm 0,002-3$ $\pm 0,002 \%$, gabah mengapur $2 \pm 0,002 \%$ dan benda asing $2 \pm 0,002 \%$. Berdasarkan data-data tersebut maka parameter-parameter mutu gabah kering giling belum memenuhi standar gabah kering giling menurut standar SNI.

Berdasarkan kinerja pemecahan kulit dari parameter beras kepala dan beras yang masih ada sekam, maka mesin dengan kapasitas penggilingan $2-6$ ton/jam memiliki kinerja terbaik. Beras kepala hasil kerja mesin kelompok ini adalah 50,07 $\pm 4,50 \%$ dengan beras yang ada sekamnya 3, 73 $\pm 0,95 \%$.

Berdasarkan kinerja penyosohan dari parameter beras pecah dan menir, dan benda asing maka mesin dengan kapasitas $2-6$ ton/jam memiliki kinerja terbaik. Beras pecahhasil kerja mesin kelompok ini adalah $41,47 \pm 1,29 \%$ dengan menir $6,2 \pm 0,2 \%$, serta benda asing 4,33 $\pm 0,81$. Mesin penyosoh terbaik adalah dengan kapasitas penggilingan $2-6$ ton/jam.

\section{Saran}

Mesin pengupas kulit gabah dan penyosoh yang beroperasi di masyarakat untuk menghasilkan beras yang berkualitas sebaiknya berkapasitas $2-6$ ton/jam, sedangkan untuk industri penggilingan gabah mesin penggiling boleh berkapasitas lebih dari 6 ton/jam, namun kualitas gabah yang digiling sebaiknya ditingkatkan sehingga memenuhi standar SNI.

\section{DAFTAR PUSTAKA}

Anonim, 1983. aryaagh.wordpress.com

Biro Pusat Statistik (BPS), 2013. Survei susut pascapanen MT. 2012/2013 Kerjasama BPS, Ditjen Tanaman Pangan, Badan Pengendali Bimas, Bulog, Bappenas, IPB, dan Badan Litbang Pertanian

Budijanto, Slamet, and Azis Boing Sitanggang. "Produktivitas dan proses penggilingan padi terkait dengan pengendalian faktor mutu berasnya." Jurnal Pangan 20.2 (2011): 141152.

Hasbullah, R., dan A.R. Dewi. 2009. Kajian Pengaruh Konfigurasi Mesin Penggilingan terhadap Rendemen dan Susut Giling beberapa Varietas Padi. Jurnal Teknik Pertanian. IPB. Vol. 23 No. 2.

Iswari, Kasma. "Kesiapan teknologi panen dan pascapanen padi dalam menekan kehilangan hasil dan meningkatkan mutu beras." Jurnal Penelitian dan Pengembangan Pertanian 31.2 (2013).

Jaya, Small Milling Performances in Lempuing, and District Dry Land. "Kinerja Penggilingan padi kecil di lahan kering Kecamatan Lempuing." (2014).

Katsuragi. Y (1995) Rice milling machine. Rice Post. Harvest Technology. The Food Agency, Ministry of Agriculture, Forestry and Fisheries. Japan pp. 351-362

Raharjo, Budi, Dedeh Hadiyanti, and Kgs A. Kodir. "Kajian Kehilangan Hasil Pada Pengeringan dan Penggilingan Padi di Lahan Pasang Surut Sumatera Selatan." Jurnal Lahan Suboptimal: Journal of Suboptimal Lands 1.1 (2012). 
Nugraha, Sigit 2012. Inovasi Teknologi Pascapanen Untuk Mengurangi Susut Hasil Dan Mempertahankan Mutu Gabah/Beras Di Tingkat Petani. Buletin Teknologi Pascananen Pertanian Vol 8 (1)

Sartika, Novi Dewi, and Zuhriyah Ramdhani. "Kajian Penggunaan Mesin Penggiling Mobile Terhadap Mutu Beras Untuk Beberapa Varietas Padi Di Kabupaten Sumbawa Barat (Study on Mobile Milling Machine Utilization in Rice Quality of Several Paddy Variety at Sumbawa Barat Regency)." Jurnal Ilmiah Rekayasa Pertanian dan Biosistem 6.1 (2018): 53-59.

SNI, 2013. Standar Mutu Beras.

Suantari, Ni Made Ayu Manik, I. GN Apriadi Aviantara, and IA Rina Protiwi Pudja. "Analisis Kinerja Sistem Penggilingan Gabah Sebagai Penunjang Usaha Pertanian Berkelanjutan (Studi Kasus di Kecamatan Penebel, Kabupaten Tabanan)." Jurnal BETA (Biosistem dan Teknik Pertanian) 6.2: 112119.
Susrusa, K.B., Y. Setiyo, Ni Luh Yulianti, dan Putu Udayani. Kajian Kelayakan Teknis dan Ekonomis Pada Proses Pengilingan Padi Untuk Menghasilkan Beras Sosoh Berkualitas. Prosiding Seminar Nasional Sains dan Teknologi Universitas Udayana.

Umar, S. 2003. Pengaruh Sistim Penggilingan Padi terhadap Kualitas Giling di Sentra Produksi Beras Lahan Pasang Surut. Universitas Mulawarman. Samarinda.

Waries, A. 2006. Teknologi Penggilingan Padi. PT Gramedia Pustaka Utama. Jakarta.

Warisno, Wowon, and Budianto Lanya Tamrin. "ANALISIS MUTU BERAS PADA MESIN PENGGILINGAN PADI BERJALAN DI KABUPATEN PRINGSEWU THE ANALYSIS OF RICE QUALITY PRODUCED BY COMMUTING RICE MILLING MACHINE IN PRINGSEWU DISTRICT."

Widowati, Sri. "Pemanfaatan hasil samping penggilingan padi dalam menunjang sistem agroindustri di pedesaan." Buletin Agrobio 4.1 (2001): 33-38. 